\title{
Characteristics Study of Land for Agriculture in Sembalun
}

\author{
Azmi Annisa Irradhiyah \\ Education Master of Geography Faculty of Social Sciences University of Padang \\ Email: azmiannisa@gmail.com
}

\begin{abstract}
This research aims to get the data, manage, analyze and discuss the characteristics of the study of Agricultural Land in Sembalun visits: 1 ) Characteristics of agricultural land, 2) Level of agricultural land suitability. This type of research is quantitative. This study population across the districts in East Lombok, amounting to 20 District of the District Keruak, Jerowaru, Sakra, Sakra West, Sakra East, Terara, Montong Ivory, Sikur, Masbagik, Pringgasela, Sukamulia, Suralaga, Selong, Labuhan Haji, Pringgabaya , Suela, Aikmel, Wanasaba Sembalun and Sambelia. Sampling in this study using Purvosive Sampling. Samples are Sembalun subdistrict. Mechanical Analysis by objective research of agricultural land characteristics observed descriptively and databulasi of the field data belongs to the growing requirements of agriculture which can be seen from the slope, soil structure, slope length, slope shape, texture soil, land use criteria. The research found that: 1) Characteristics of agricultural land in Sembalun, had several criteria: a slope in the category Sembalun including steep or less suitable for agriculture by $46-65 \%$ kemiringin slope, soil to soil Sembalun criteria granular, blocky or appropriate agricultural land and have long used the medium to long $15-50 \mathrm{~m}$, soil texture Sembalun criteria belong to the category of rough because it is composed by sand-plated, dusty sand, slope shape in Sembalun belong to the variation convex with dignity 2 for observation location along notching it is always a convex slope, land use Sembalun belong to the criterion of berlukar / mixed farms with dignity 2. Because along the way, the land berlukar / mixed farms. 2) Suitability of farmland in Sembalun based on the results of pengharkatan to 6 land characteristics, the number value obtained was 12 with class suitability for agricultural land belonging to the class I (land suitable for agriculture).
\end{abstract}

Keywords: Characteristics of Agricultural Land, Agricultural Land Suitability

\section{Introduction}

Indonesia is an agricultural country that produces varied results agricultural production and plantation, one of which is agricultural production is fruit plants. Fruit plants are plants that produce fruit edible (consumption) in a fresh state, either as a table fruit or processed materials and generally not stored longer lasting. Fruit is a commodity will be developed, to accompany the cultivation of food crops, because the results production is likely to gain greater profits. In This free trade era, need to be initiated and developed fruit quality to be exported (Susanti and Winiarti 2013). Soil is a natural three-dimensional body which is where the activity of all living creatures, including the growth of plants. Land has characteristics that affect plant growth to be commercialized. Soil classification and land evaluation is one way to determine the suitability of a land to develop agricultural crops (Hardjowigeno, 2007).

Soil has different characteristics from one place to another because in the ground, there is a diversity of physical processes, chemical and biological work in spatio-temporal and with varying intensity. With diverse land characteristics, use of land for the cultivation of a commodity requires specific inputs in accordance with the characteristics of the land. Provision of a uniform input for diverse land characteristics can cause shortage of inputs in several places, but can cause excess input elsewhere. Put that does not comply with the characteristics of the land will not be effective and may even be a waste, both in terms of capital inputs and land resources. In the management of land resources of the future, providing a specific input area 
is necessary. Local specific input is of course a function of many aspects including the soil, topography, climate and infrastructure. In fact, the harvest is the result of a complex of many factors including soil, climate and the environment, so that the input needs to be determined in accordance with the (Widiatmaka, Wiwin Ambarwulan et al., 2016). In addition, soil testing is also important in the evaluation of land (Niekerk, 2010) during continuous land management planning, but the quality of land use is considered as a tool for predicting the suitability or potential land (Rossiter, 1996). Soil is a mixture of minerals and natural organic matter to form, structure, and composition definite (Buckman and Brady, 1969; Hardjowigeno, 2003). Soil bearing capacity is defined as the natural ability to fully support the growth of human, physical development or exploration of human resources without damaging natural ecosystems (Kaiser et al., 1995; Setyaningrum, 2003). In classifying the land use, land for residential purpose must correspond with a conducive environment (Masri, 2012) due; Improvement of human existence in a region can disrupt an entire neighborhood (Naqvi et al., 2014; Rusdi Muhammad, Ruhizal Roosl et al., 2015).

The land has a different potential in supporting the growth and development of a plant. Therefore, evaluation of land suitability for agriculture systems widely use is indispensable in order to obtain a suitable land for agricultural plant growth and development according to his ability. Land use types of plants can be optimized according to land suitability evaluation approach. Land use development planning becomes less good if it does not pay attention to the suitability of land (Astuti, 2010). Land management is currently focused on the concept of sustainable land management. Sustainable land management paradigm implies that in meeting the needs of our current, current management trends should not diminish the ability of natural resources to meet the needs of future generations (Sukardi et al., 2017).

Carrying capacity of agricultural land is not a fixed quantity, but varies according to time due to changes in technology and culture. Technology will affect the productivity of the land, while the culture will determine the needs of each individual life. Therefore, the calculation of the carrying capacity of the land should be calculated from the data collected long enough to be able to describe the state of the actual area. Variations level land capacity and the factors that influence due to differences in the aspects of population, natural resources and control or management. This fact suggests that the determination of the policy, especially the selection and determination of resource allocation and priority programs for development should be done with caution and prudent to always pay attention to the situation, conditions and potential of the local area (Moniaga, 2011). Construction land suitability evaluation refers to comparing the quality of the land with the quality requirements of construction land in a specific research area, and the goal is to determine the suitability of the construction land. In the process of construction land suitability evaluation, development evaluation index system is a very important step. System is a good indicator not only be able to fully reflect the level of quality of construction land in the study area, but also to determine the sustainability of land use construction (Yu, Zhang, Chen Xudong, 2016). Like other regions in Indonesia, East Lombok is also a tropical climate characterized by two seasons, summer and rainy season. Average rainfall of $1882 \mathrm{~mm}$ / year with the number of rainy days per month 15 days. The District of wet in the rainy season is the District Aikmel, Suela, Sembalun, Masbagik Pringgasela, Ivory Montong. While the dry area is the District Keruak and Jerowaru with an average rainfall of $1,080 \mathrm{~mm} /$ year.

This area has a great potential to be developed, the potential of agriculture in East Lombok are rice, corn, soybeans, peanuts, cassava, sweet potato, green beans, onions, garlic, peppers, eggplant and tomatoes. For plantation crops in this area such as cloves, cashew, cocoa, cotton, coconut, robusta coffee, pepper, tobacco. Northern region is a fertile agricultural area and the slopes of Rinjani with a height of 3,726 m. This area has the potential for the development of agro-industries. Meanwhile, the southern region is an area of dry land with relatively low rainfall, but the area is very potential for the development of agricultural commodities such as tobacco Virginia. In the agricultural sector Lombok east almost all districts chili eastern potential in agriculture, District Sembalun one of these districts is an area of very high potential to be 
developed into an area of agro-industry because has a lot of crops such as carrots, potatoes, strawberries, onion and garlic white. In land use are the problems related to the economic development of the region, such as problems in the farming region. Problems utilization of agricultural land, especially food crops with a high population pressure and the dependence of life on the farm so that the resulting land use land due attention in terms of the ability of the soil and the use of space, attention to the rules of soil conservation, it can accelerate the decline in the carrying capacity of the soil and environmental quality.

\section{Method}

Research on Agricultural Land Characteristics Study On Sembalun. This type of research is quantitative. This research was conducted in July in East Lombok West Nusa Tenggara. The population in this study were all districts in East Lombok. There are 20 districts, namely Keruak, Jerowaru, Sakra, Sakra West, East Sakra, Terara, Montong Ivory, Sikur, Masbagik, Pringgasela, Sukamulia, Suralaga, Selong, Labuhan Haji, Pringgabaya, Suela, Aikmel, Wanasaba Sembalun and Sambelia. Sampling in this study using Random Samplingtechnique.The type of data in this study no secondary data and primary data. Data collection techniques in this study for the purpose of 1) characteristics of the land and 2) the degree of suitability, in this study distinguished on the slope, drainage, structures. Mechanical analysis based on objective research Quantitative observed land characteristics and tabulation of the data field belonging to the growing requirements of agriculture which can be seen from the slope, soil structure, slope length, soil texture, slope shape, and land use.

\section{Results and Discussion}

East Lombok is part of the province of West Nusa Tenggara. Located on the island of Lombok, with a capital of Selong. The area of East Lombok $2679.88 \mathrm{~km} 2$, consisting of the land area of $1605.55 \mathrm{~km} 2$. East Lombok Regency consists of 20 subdistricts and 254 villages. East Lombok has incredible natural wealth with a variety of diversity and potential. The tourism sector as one of the economic assets have significance for the regional economy because it is dominated by the assets of the natural wealth in the form of a number of small islands and beaches, rich farmland and mountains. Sembalun the name of an upland areas in Lombok Island, located in the northeast of the island of Lombok at an altitude of about 1,200 meters above sea level (masl), as well as being part of the volcano area, the Mount Rinjani (3,726 masl).

The topography of Sembalun surrounded by hills with the highest peak on Mount Rinjani where there Segara Chicks. Some of these hills is an area of jungle and grassland region. From the hillside there are springs and river water flows into the fountain and the population on the island of Lombok. Based on the topography of an area, East Lombok is situated at an altitude of between 0 to 3.726 meters above sea level with kemiringin slope varies from class kemiringin slopes between $0-2 \%$ to kemiringin class slopes of more than $40 \%$. The results of calculations of East Lombok BPN stipulates that:

1. Class of slope between $0-2 \%$ is in the form of plain area are scattered in the District Jerowaru, Keruak, Labuhan Haji and Pringgabaya a total area reaches 25760 ha.

2. Class slope between 2-15\% spread in the District of Sakra, Sakra West, East Sakra, Masbagik, Pringgasela, Aikmel, Wanasaba, Suela and Sambalia with total area reached 96.763 hectares.

3. Between $15-40 \%$ slope class includes the District Suela and most of the District of Sembalun.

4. Grade slope of more than $40 \%$ of mountainous areas rinjani with a total area of 13-810 hectares.

5. As for the spread of soil types based on the subdistrict that is obtained picture as follows: 
6. Soil types grumosol scattered in the District Keruak, Jerowaru, Terara, Montong Ivory, Sikur, Sukamulia, Suralaga, Selong, Labuhan Haji, partly Aikmel, Wanasaba and part of the District Sembalun, with Kabputen spacious East Lombok.

7. The District has an area Keruak and Jerowaru grumosol 18462 ha (11.50\%), while the District Sukamulia and Suralaga only 23 hectares.

\section{Conclusion}

1. Characteristics of agricultural land in Sembalun on a slope that is $46-65 \%$ belong to the category of steep land for agriculture, meaning less suitable land turned into a farm. Soil structure belonging to the granular soil criteria, blocky, land suitable for agriculture. Length slopes in Sembalun classified in the category of medium to long length of $15-50 \mathrm{~m}$ and on this slope land appropriate for agriculture due to land and adequate length. Criteria soil texture belonging to the category of rough because it is composed by sand clay, sand dust. Shape belonging to the variation convex slopes, this is due to the formation of the slope along the observation location is always convex.

\section{References}

Astuti, Fery Dwi. (2010). Land Suitability For Plants Peanut (Arachis Hypogeae) in Karanganyar. .Journal of Soil Science.

Hardjowigeno, Sarwono. (2007). SoilScience. Jakarta: Rajawali Press.

Khairani and Hermon. (2009). Soil Geography. Padang: UNP Press.

Kii, Masanobu, Kazuki Nakamura. (2016). Development of a suitability models forestimation of global urban landcover. World Conference on Transport Research - WCTR 2016 Shanghai. July 10-15, 2016.

Mahi. AK (2005). Evaluation and Land UsePlanning.Faculty of Agriculture. University of Lampung.Bandar Lampung.

Moniaga, Vicky RB (2011). Carrying Capacity Analysis ofAgriculture.Volume 7 No. 2.

Rusdi Muhammad et al. (2015). For Land Suitability Evaluation Settlement Based On SoilPermeability, Topography Geology and Ten Years After Tsunami in Banda Aceh, Indonesia. The Egyptian Journal of Remote Sensing and Space Sciences (2015) 18, 207-215.

Sukardi and Ismail. (2017). Estimated Carbon Absorption and Economic Benefits in Various Scenarios of Community Forest (HKM) Land Management Through The Scheme of Plan Vivo in The Upstream Watersheds (DAS) of Renggung River, Central Lombok Regency, Indonesia. Universitas Mataram, Indonesia. Journal of Disaster Sumatra, Geography and Geography Education

Susanti, Winiarti. (2013). Expert System Suitability Determination of Agricultural Land Crops $\quad$ Fruit Bachelor of Engineering Informatics Journal. Volume 1 No. 1.

Yu, Zhang, Chen Xudong. (2016). A Study On The Choices Of Construction LandSuitability OfEvaluationEcologicalIndex.Information Technology and Quantitative Management (ITQM 2016).

Widiatmakaa et al. (2016). Remote sensing and land suitability analysis to establishlocal specific inputs for paddy fields in Subang, West Java. Journal. 